\title{
Free Labour, Social Media, Management: Challenging Marxist Organization Studies
}

Armin Beverungen - Leuphana University Lüneburg (armin.beverungen@leuphana.de)

Steffen Böhm - University of Essex (steffen@essex.ac.uk)

Chris Land - University of Essex (cland@essex.ac.uk)

Final version of paper accepted for publication in Organization Studies as part of the Marxist Forum in edited by Paul Adler, Rick Delbridge and Matt Vidal.

\begin{abstract}
In this paper we explore how so-called 'social media' such as Facebook challenge Marxist organization studies. We argue that understanding the role of user activity in web 2.0 business models requires a focus on 'work', understood as value productive activity, that takes place beyond waged labour in the firm. A reading of Marx on the socialization of labour highlights the emerging figure of 'free labour', which is both unpaid and uncoerced. Marxist work on the production of the 'audience commodity' provides one avenue for understanding the production of content and data by users as free labour, but this raises questions concerning the distinction between productive and unproductive labour which is central to Marx's labour theory of value. The Marxist literature on 'the becoming rent of profit' allows for a partial understanding of how the value produced by free labour is captured, thereby developing the understanding of the economic dimension of 'free labour' as unpaid. It overstates, however, the 'uncontrolled' side of 'free labour', and neglects the ways in which this work is managed so as to ensure that it is productive. We therefore call for a return to Marxist labour process analysis, albeit with an expanded focus on labour and a revised understanding of control associated with digital protocols. On this basis, a Marxist organization studies can contribute to an understanding of the political economy of digital capitalism.
\end{abstract}




\section{Introduction}

By nearly any measure, Facebook is an impressive phenomenon. Founded in 2004, by September 2012 it recorded over one billion monthly active users, and more than half a billion daily active users (Facebook, 2013). It is the second most visited website in the world, behind Google. Many of us now blog, chat, play, learn, listen to music, watch videos, read news and organize events on Facebook. By 2012, its users were sharing 'four billion pieces of content per day, including uploads of 250 million photos', and the site itself was connected to 'seven million websites and applications' (Wilson et al., 2012, p. 203). More than ten years after the dot-com bubble left the Internet economy in tatters (Henwood, 2003), Facebook's initial public offering (IPO) valued the company at over $\$ 100$ billion dollars, making it the largest IPO for a new technology company ever. The company's reported revenues for 2012 were more than $\$ 5$ billion, of which $84 \%$ ( $\$ 4.3$ billion) came from advertising (Facebook, 2013). The case of Facebook is breath-taking, then, both in quantitative terms, and in the way that it qualitatively channels and reconfigures our sociality (Gregg, 2011; Miller, 2011).

In this paper we explore Facebook as an exemplar of social networking sites and what has become known as 'social media' or the 'web 2.0' (see Fuchs, 2014a). Our concern is to understand the challenges these present to Marxist organization studies, and to clarify what Marxist organziation studies can bring to their analysis. The scale and significance of this challenge is clear from a cursory glance at Facebook's accounts. At the end of 2012, the company had revenues over $\$ 5$ billion with only 4619 staff, each generating over \$1 million in revenue (Facebook, 2013). Such figures can hardly be explained through the hyper-productivity of Facebook's employees, but require an account of other types of labour. Besides the wage labour involved in activities such as maintaining servers, managing the website, coding algorithms for data extraction, and selling advertising to Facebook's clients, there is also outsourced labour, e.g. from the Global South keeping the site 'hygienic', i.e. free from offensive or explicit content (Lanchester, 2012). There is also much unpaid, expert labour at work, such as the work of translating interfaces into different languages, which Facebook has crowdsourced in the past (Scholz, 2010, p. 244). Marxist organization studies already understands wage labour and outsourcing, but has so far had little to say about crowdsourcing and other forms of free labour.

Facebook users produce content by updating their status, uploading photos, liking, commenting, messaging, and playing on-line games through the platform. This activity has traditionally not been understood as labour, yet Facebook's business model relies heavily on what we argue should be understood as the 'free labour' (Terranova, 2004) of users. In our view, social media and the web 2.0 pose a challenge to Marxist organization studies because of the way Facebook organizes the activities of its users to turn them into productive labour, as we argue below. Where social media and the web 2.0 promise sociality - even though 'the Web has always been social' 
(Scholz, 2008) - this sociality is channeled through specific platforms such as Facebook on which it can be captured, and is managed and thereby made productive. This dual process ensures that what appears, at first glance, to be a free activity of communication, is in fact a form of 'free labour'. The web 2.0 thus constitutes a continuation of capital's attempt to valorize social labour, while making workers believe 'that digital labor does not exist' (Scholz, 2010, p. 243; DyerWitheford, 2009; Lovink, 2011; Scholz, 2008).

To date, organization studies has paid little attention to digital labour (Burston et al., 2010; Scholz, 2012) and whilst there has been some work on Facebook (e.g. Grassman and Case, 2009; Muhr and Pedersen, 2011), it has not developed a Marxist perspective in terms of digital labour. In the first section of this paper, we suggest that this neglect results from the restrictive conception of labour that dominates Marxist analyses and focuses on paid employment in forprofit firms and other organizations. Drawing on the intuitions of paleo-Marxist (Adler, 2007) and post-workerist Marxist perspectives (Harney, 2007; Fleming and Mandarini, 2009), we suggest that a focus on the socialization of labour can extend Marxist organizational analysis beyond traditional labour processes (Böhm and Land, 2012). It enables an expanded focus on labour that moves Marxist analyses away from the point of production on the factory shop-floor the 'hidden abode' of classical Marxism (Marx, 1976: 279) - to account for the 'free labour' (Terranova, 2004) without which we cannot understand Facebook's business model.

In the second section, we revisit the 'audience commodity' framework developed by Smythe in the context of mass media and recently reactivated by Fuchs in the context of digital media (Smythe, 1977; Fuchs, 2014b). This by now classic, but still contested, Marxist approach suggests that Facebook's users work for the company in various ways, most notably by producing content and data that enables Facebook to sell targeted advertising. In this section, we outline the debates between those who see user activity as productive labour (e.g. Andrejevic, 2012; Fuchs, 2014b) and those who argue it is unproductive or non-productive (e.g. Arvidsson and Colleoni, 2012; Caraway, 2011), noting that the productivity of such 'free labour' is highly contested and cannot just be assumed (Terranova, 2004; Harvie, 2005). While providing a powerful explanation of how user labour may be conceptualized to better understand Facebook's business model, we argue that the 'audience commodity' approach needs further work to analyse the means by which this free labour is captured and managed.

In the third section, we therefore explore how free labour is captured. Here we review the idea of 'the becoming rent of profit' (Marazzi, 2010; Vercellone, 2010), which implies that capital increasingly becomes dependent upon forms of free labour that are not directly managed. Instead, capital extracts value from a distance, rather than exercising direct control over it. We distance ourselves from the more exuberant aspects of this literature, such as the erosion of any difference between productive and unproductive labour (see Henninger, 2007; Smith, 2013) and the 
apparent simplicity of the concepts of control that allow the claim to be made that labour is now autonomous. The privatised platform of Facebook separates the users from their means of socialization, creating 'walled gardens' and an artificial scarcity of user data (Scholz, 2010), which the company can then valorize by selling targeted advertising. While the argument regarding 'the becoming rent of profit' situates Facebook within a wider analysis of the development of digital capitalism, it overstates the distance capital takes from labour, and must hence be complemented with an analysis of how free labour is managed and made productive.

In the final section, we explore how the free labour of Facebook users is managed. We argue that many of the company's direct employees effectively act like managers by, amongst other things, designing the website to encourage content and user-data production, and coding algorithms for data extraction. They therefore embody a dual position, as Marxist labour process analysis has long argued (Armstrong, 1989; Willmott, 1997), simultaneously controlling labour and directly contributing to the production process. Facebook's employees are contributing directly to commodity production (both the platform, which is not actually sold, and the packaging of data and targeting of advertising, which is their real product), and they are managing the labour of users by structuring the possibilities for communication via the platform. As control here is indirect and largely functions through the privatized infrastructure and means of communication (Andrejevic, 2012; Fuchs, 2014b), we propose the concept of 'protocological control', inspired by Galloway (2004), as a way of understanding these forms of control at a distance through (digital) code, algorithms and protocols, and outline three ways in which this sort of control is exercised on Facebook.

\section{Marxist organization studies, socialization and free labour}

In this section of the paper, we explore why Marxist organization studies have so far paid little attention to unpaid labour, before arguing that the socialisation of labour opens up such analyses to what some commentators have called 'free labour' (Terranova, 2004). In Capital Volume 1, Marx asked his readers to follow him into 'the hidden abode of production' in order to lay bare the 'secret of profit-making' (1976, p. 279-280; Böhm and Land, 2012). This is a pivotal moment in Capital since Marx argues that it is within this 'hidden abode', where the labour process is managed and controlled, that surplus value is produced. This focus on the labour process also brings forth the figure of productive labour, which contrasts with unproductive and nonproductive labour. Marx writes that the 'only worker who is productive is one who produces surplus-value for the capitalist', so that 'the only productive labour is that which is directly consumed in the course of production for the valorization of capital' (1976, p. 644, 1038; emphasis in original). Hence, for many Marxists unproductive and non-productive labour are of 
less importance as they do not directly contribute to production and do not generate surplus value.

Even though Marx's theory of value is extensive, his comments on the definitions of productive and unproductive labour were 'brief and fragmentary' (Meiksins, 1981, p. 33). This has led many Marxists to attempt a coherent interpretation of his position (e.g. Meiksins, 1981; Mohun, 1996; Harvie, 2005). Productive labour is usually defined rather restrictively as that labour contributing directly to the production of surplus-value. Labour that does not directly produce surplus-value is thus designated as 'unproductive'. This includes: that part of the labour of managers merely concerned with enforcing capitalist command; all labour employed in the circulation of commodities, rather than their production; and the work provided for revenue and not part of production. Mohun (1996, p. 36, 38) adds that all non-waged labour is 'non-productive' since it does not enter calculations of value at all.

Much of the groundwork for Marxist studies of organization was provided by Braverman (1974) who placed this Marxist focus on productive labour at the heart of its labour process analysis (see Beverungen, 2009). Yet what established itself as labour process theory (LPT) from the 1990s onwards has developed along at least two contending theoretical currents. On the one hand, attempts to consolidate one current around a 'core theory' (Thompson, 1990) came hand in hand with a disavowal of Marx's labour theory of value, and even Marxism altogether. Despite some Marxists critiquing the narrow focus of 'core theory' (see Jaros, 2005), and some recognition within this strand of LPT of the need to situate the labour process within a political economy (e.g. Thompson and Smith, 2009, p. 923), this current restricted its focus to paid employment. In an opposing direction, another current sought to maintain a strong engagement with Marxism at the heart of LPT, working with value theory and concepts central to the Marxist analytical project (e.g. Rowlinson and Hassard, 1994; Lucio and Stewart, 1997; Spencer, 2000). For example, Matt Vidal (2013: 605-606) uses an explicitly Marxist analysis of the division of labour and value to demonstrate how 'the postfordist regime still systematically generates a job structure with a large percentage of low-autonomy jobs and increasingly produces a stratum of long-term working poor, whose wages are kept low by the existence of various strata of a reserve army of under- and unemployed.' Whilst this current equally developed an impressive empirical programme, it also limits its analysis to paid employment. In so doing, both currents exclude other forms of value productive activity and exploitation that are conventionally coded as consumption or reproduction, including social networking sites and other forms of free labour.

A different inheritance of Marx is to be found in the work of Adler, who has offered one of the most prominent Marxist critiques of LPT (Adler, 2007). In contrast to 'neo-Marxist' LPT, Adler's own 'paleo-Marxist' position reinstates the contradictions between the forces and relations of production as the key historical dynamic of capitalism. As technology and 
organization develop, he argues, capitalist relations of production find themselves in contradiction with the socialization of the forces of production. The socialization of labour brings forth the figure of the socialized or 'collective worker' (Adler, 2007: 1321) or (this is a matter of translation) 'associated labour, or labour in common' (Marx, 1976: 508). Adler's take on socialisation and the collective worker as well as Heckscher and Adler's (2006) notion of 'collaborative communities' both point beyond the factory or office shop-floor and toward the idea that the production of social relations themselves might be 'productive'. Despite this, however, Adler's concerns remain with 'grasping the everyday contradictions of the capitalist firm' (2007: 1339) and his examples are exclusively of paid employment.

A further strand of Marxist organization studies, associated with post-workerist Marxism, also explores this socialization of labour (Mandarini, 2005). Harney, for example, draws on feminist readings of Marx (Dalla Costa and James, 1975) to emphasize that 'the work of socialization - all that labour does without wage recompense to make this regime [of wage labour] possible both in the workplace and the community - are present from an incipient moment in commodity labour' (Harney, 2007, p. 148). Even though this socialisation of labour brings with it an 'anti-capitalist politics' and forms the basis of social wealth, it also serves as a source of profit for capital (ibid.). In contrast to Adler (2007), for post-workerists this is not a form of contradiction but of antagonism, and the wage relation is a part of, but not the totality of, capital's command over labour. The concept of the 'social factory' extends this analysis, noting how this antagonism spreads as 'labouring processes have moved outside the factory walls to invest the entire society' (Hardt and Negri, 1994, p. 9; Fleming and Mandarini, 2009).

These conceptions of the socialization of labour and the social factory point beyond the labour process as mediated by the wage relation towards a new 'hidden abode' of production, where work occupies an expanded terrain of social activity; where management moves further away from direct control of work to more complex practices of governance (Arvidsson, 2005); and where collaboration in production is increasingly the responsibility of the workers (Böhm and Land, 2012). This is not to say that distinctions between productive and unproductive labour, or Marxist value theory in toto, is obsolete (Henninger, 2007). Nor is in to say that the employment relationship is becoming irrelevant. Far from it. Many of the prophecies of the 'end of work' have been overstated (Caffentzis, 1999; Cleaver, 2001). Yet, as Caffentzis notes, with this 'discovery' of housework and other forms of unpaid work, such as 'off-the books' work and coerced labour, 'we are forced to recognize an intersecting and self-reflective manifold of energetic investments that dwarf the "formal world of work" in spatio-temporal and value terms' $(1999$, p. 22; see also Ross, 2012; Hartmann, 1979).

What arises from these analyses is that the restrictive definition of productive labour outlined above needs to be extended to also account for developments in the socialization of labour and 
unpaid work. This challenge is clearly expressed in Terranova's concept of 'free labour', which for her constitutes an ignored but important source of value in the contemporary economy (2004: 73).

Simultaneously voluntarily given and unwaged, enjoyed and exploited, free labour on the Net includes the activity of building web sites, modifying software packages, reading and participating in mailing lists and building virtual spaces. Far from being an 'unreal', empty space, the Internet is animated by cultural and technical labour through and through, a continuous production of value which is completely immanent in the flows of the network society at large. (Terranova, 2004: 74)

Insofar as free labour is 'voluntarily given' and 'unwaged', it directly challenges the definitions of productive labour and its conditions as summarized, for example, by Mohun (1996), who restricts the category of productive labour to work that is both waged and controlled by capital in the production process. It also challenges Marx's own conception of the capitalist labour process, wherein the 'free worker' (1976, p. 274) sells his or her labour power in order to work 'under the control of the capitalist to whom his labour belongs' and where 'the product is the property of the capitalist and not that of the worker' (1976, p. 291-292).

Harvie (2005) reflects on classical Marxist positions (e.g. Mohun, 1996) in light of these developments and suggests that we must rethink our definitions of labour. Divisions between productive and unproductive labour are increasingly difficult to sustain as 'productive and unproductive labours become commingled' and even non-productive labour is subjected to capitalist measure (Harvie, 2005, p. 160). Harvie therefore proposes that we understand productive and unproductive labour as categories of struggle, suggesting that, where capital tries to make all labour productive, the aim of labour struggle is to become unproductive (ibid., p. 160161). In the following sections, we build upon this point by examining Marxist debates over both old (broadcast) and new (digital, social) media, and their implications for understanding media consumption in terms of productive and unproductive labour. In reviewing these debates we follow Harvie (2005) in focussing on capital's attempts to capture free labour and to make it productive, and on how this labour is disguised as non-work 'often by refusing to remunerate it' (Henninger, 2007, p. 174).

\section{Producing the audience commodity}

Facebook is not the first media company that challenges Marxist conceptions of labour in the way its business model leverages the 'work' of users. In his study of mass media, Smythe (1977; 1981) argued that mass media were selling an 'audience commodity' that is sold to advertisers. 
Audiences of mass media contribute to the production of this 'audience commodity' through the attention they give to advertising as part of their media consumption. Audiences' viewing of television, for example, should be understood as labour because it is the primary activity that produces the commodity - audience attention - that is sold to advertisers. More recently, this model has been adapted, most prominently by Fuchs (2014b), to account for digital media like Facebook (see also e.g. Coté and Pybus, 2007; Andrejevic, 2009). In this section, we briefly explore this approach to understanding audience/user activity as labour, explaining how the model has been adapted to digital media, and discussing the main criticisms. Whilst appreciating the basic point that the 'labour' of users is central to the production of value in digital capitalism, we suggest that this approach does not fully explain how such free labour is captured and rendered productive in digital media.

Smythe $(1977 ; 1981)$ challenged the dominant Marxist reading of mass media, which saw their primary function as ideological by focusing on the role of the media in producing capitalist society (Adorno and Horkheimer, 1997). Instead, Smythe understood their function in monopoly capitalism in terms of the commodity they sell. In his view, what gets sold to advertisers is audience attention: 'the services of audiences with predictable specifications who will pay attention in predictable numbers and at particular times to particular means of communication' (Smythe, 1977, p. 4). Smythe noted that these commodities were highly differentiated products, that as 'collectivities' audiences were traded as commodities in markets, and that their value was checked by market research agencies (ibid., p. 4-5). He did so in order to establish that advertising involves commodity production and is therefore productive, as advertising is a key function of the 'demand management' required as part of production in monopoly capitalism (Smythe, 1977, p. 4; see also Caraway, 2011). In Smythe's view, the denial of advertising's productivity was 'unnecessary and divisionary: a cul de sac derived from the pre-monopolycapitalist stage of development' (1977, p. 16).

Smythe also sought to establish that, while the audience commodity was sold by the mass media companies, it was produced by the audiences themselves, who therefore worked for the advertisers. By learning to spend their income on certain brands, 'they work to create the demand for advertised goods' while 'simultaneously reproducing their own labour power' (Smythe, 1977, p. 6). The 'audience power' realized in this work is a labour power like any other, Smythe argued, which however was acquired 'dirt-cheap'. Therefore, its productivity did not need to be particularly high 'in order for it to be profitable for advertisers to recoup the costs - to them - of putting audience power to work' (1981, p. 233, 239). From this argument it follows that mass media audiences are performing productive labour in the sense that as an 'audience' they are commodified and have exchange value in the marketplace when sold to advertisers. Without the 'work' of audiences, there would be no commodity to sell. 
Smythe's argument was contested, as advertising was mostly seen to not be part of production but circulation. In the classical Marxist formulation, circulation labour was deemed unproductive as it is paid out of profits derived from production (see e.g. Mohun, 1996, p. 37; cf. Harvie, 2005). Furthermore, even if advertising involved unproductive labour, this would normally be the work of those employed by advertising agencies, rather than the audience, which was neither paid nor aware of being involved in a labour process (cf. Arvidsson, 2005). To address the issue of pay, Jhally and Livant (1986) suggested that audiences were remunerate by the programming they received in return for their attention. Articulating a more conventional Marxist analysis, Caraway insists that even if audiences were aware of the barter involved, their labour simply does not correspond to the criteria for productive labour, since it was neither paid nor clearly under the control of the capitalist (2011, p. 696-698). While Caraway insists on Marx's definition of productive labour discussed above, this definition is precisely what Smythe sought to challenge in his analysis, thereby pointing to the need to develop and adapt Marxist categories like labour and value to fit the empirical object of analysis. When we move from the study of mass broadcast media to digital social media, and from audiences to users, the argument takes on a new dimension.

Fuchs (2014a; 2014b) is the most prominent contemporary proponent of the audience commodity thesis, applying it to a critical understanding of the Internet and social networking sites and noting that only one of the ten most accessed websites, i.e. Wikipedia, does not use a free access, advertising-funded business model. Fuchs largely agrees with Smythe's analysis, while dropping some aspects, such as situating the argument within an analysis of monopoly capitalism. In his view, the main difference between the audience commodity of mass media and that produced on the Internet is that users also produce content: they 'engage in permanent creative activity, communication, community, building, and content-production', so that Facebook's audience commodity is an 'Internet prosumer commodity' (2012a, p. 146). Without the status updates, photographs, 'likes', 'recommends', comments, posted video clips, and fan pages that its users create, Facebook would have nothing to draw an audience that it can sell to advertisers. The audience's attention is produced by users both in their participation as an audience to other users' content, and through their own production of content, which constitutes others as an audience.

Another way in which the Internet prosumer commodity differs from Smythe's audience commodity is through the personal data that Internet usage produces. Social media platforms are not ultimately interested in content at all, which can even disturbs the cleansed space of advertising (Andrejevic, 2009, p. 412). While producing and consuming content, however, users generate data that can be commodified directly and for profit. Whether through the content they post on their profile and the pages they 'like', or through their mobile phone's GPS and their web-browsing history, these sites can extract significant amounts of data from users. Facebook commodifies this data and sells it to advertisers who can deploy it in market research and in 
targeting specific advertisements (Fuchs, 2012a, p. 147). Facebook's platform - and the paid work that goes into it - facilitates and manages the gathering of rich user data, enabling sophisticated studies of consumer behaviour via data mining, predictive analysis and even sentiment analysis (Andrejevic, 2011).

The audience commodity approach, then, makes a strong case for understanding the activities of audiences and users as labour, whether productive, unproductive or non-productive. The case is even more forceful once the approach is applied to social media and platforms such as Facebook. In contrast to the relatively passive audience of broadcast media, the users of social media are proactively involved in the production of content and data, and even take on some of the work traditionally performed by media professionals. However, this difference is not to be overstated, as cultural studies has long considered audiences to be active, at least with regards to interpretation and the production of meaning (Caraway, 2011: 698). Nonetheless, whether this 'audience labour' be considered as productive labour, in Marxist political economic terms, however active its consumption, still needs to be addressed.

One issue is that recent adaptations of the audience commodity approach to digital media contributes little to an argument for why advertising as such should be considered productive. This would be a precondition for understanding any labour involved in creating the Internet prosumer commodity as productive, rather than unproductive since merely involved in circulation, not production (cf. Meiksins, 1991; Mohun, 1996). The argument regarding the importance of advertising in demand management for monopoly capital in Smythe (1977) is not reproduced or replaced in analyses of digital media. Arvidsson (2005) makes the case, however, that advertisers draw on social creativity to produce brands and invest them with meaning, which is reproduced as sign value through the act of consumption. That such processes now take place and are organized on Facebook means that users do not merely learn to consume but contribute to the production of brand value. In a context where the exchange value of many commodities derives from their brand value, this work is thus directly productive (Arvidsson, 2005; Land and Taylor, 2010). In contrast, Fuchs (2014b, p. 115) at times even rejects such a line of argument, when he suggests that branding merely contributes to the price-value differential, so that branding work does not constitute productive labour. A broader account of the role of advertising and branding within valorization is therefore required here.

A second issue concerns whether any form of unpaid labour should be considered productive at all. As noted above, unpaid labour is usually considered by Marxists to be non-productive - that is, neither productive nor unproductive - since it only produces use values and no value, simply because 'there is no social mechanism for commensurating different labor activities', so there is no measure for it being 'socially necessary' (Mohun, 1996, p. 38). Capital 'has always relied on 'free gifts' produced outside the capital form' (Smith, 2013, p. 251), and for Smith it is merely a 
matter of adding e.g. crowdsourced software code to such a list of free gifts (ibid.). However, a case can be made that we are dealing here with more than free gifts. For social media such as Facebook, user-generated content replaces content produced by paid journalists and editors for mass media. As the labour of these media professionals is now effectively in competition with amateurs (Ross, 2012), their labour is commensurate. Even if capitalism always relied on free gifts that it 'claimed as its own' (Smith, 2013, p. 243), Facebook's success may be based on it being able to capture more of those gifts and have its users produce even more.

While the two issues above can arguably be resolved, a key question remains. As Caraway in particular noted, Smythe provided 'no meaningful analysis' for how audience labour fulfilled two conditions of productive labour, namely that the labour process was controlled by capital and that the product is appropriated by capital (Caraway, 2011, p. 697; Marx, 1976, p. 291-292). How can Smythe claim that labour can be controlled and its products appropriated, without it being waged? Indeed, in the accounts of Fuchs, Andrejevic and others reviewed above, little argument is forthcoming on how precisely user labour is captured and controlled, apart from vague accounts of how audiences are attracted and data is extracted. Yet if the free labourer does not receive a wage to in return relinquish control over the labour process and the product of that labour, why and how is her labour freely given and made to yield value for the capitalist?

Caraway proposes an alternative account to Smythe's, and by implication to Fuchs', namely that no productive labour by audiences or users is involved at all but instead media owners charge a form of rent to advertisers who want to access audiences via the respective media (2011, p. 701). It is not a matter of profit being extracted from productive labour (audience labour), but of rent being extracted from exclusive access to scarce resources (audience attention). In so arguing, however, Caraway effectively takes a step back from the analysis above and ignores the way these media companies organize the activities of audiences and users, and how users themselves contribute to producing audience attention. As we will argue further below, various aspects of Facebook's platform can be seen to both capture and manage free labour. While it is therefore not simply a matter of extracting rent, arguably it is a matter of 'the becoming rent of profit' (Marazzi, 2010; Vercellone, 2010), wherein profit is increasingly extracted, much like rent, from a distance of the labour that produces the commodity sold, in this case audience attention.

\section{Capturing free labour by digital means}

The audience commodity approach, then, makes a strong case for considering the activities of audiences and users as labour, but does not provide much of an explanation for how that free labour is captured and controlled. In this section we therefore engage further with post-workerist currents of Marxism, particularly those who, through a reading of Marx on the 'general intellect' 
(Vercellone, 2007; Virno, 2007), understand the capture and control of free labour through 'the becoming rent of profit' (Marazzi, 2010; Vercellone, 2010). Central to Vercellone's analysis is the idea of the 'general intellect', which develops out of a reading of the 'Fragment on Machines' in the Grundrisse (Marx, 1973) and identifies knowledge 'as the main productive force' of cognitive capitalism (Virno, 2007, p. 5). Rather than knowledge embodied in capitalist machinery as fixed capital, Virno suggests that 'mass intellectuality' is how the general intellect manifests itself today, and he defines this mass intellectuality as 'the entirety of post-Fordist living labour... to the extent that it is the depository of cognitive competencies that cannot be objectified in machinery' (Virno, 2007, p. 6).

Once labour organizes production independently, Vercellone argues, profit 'derives from a simple appropriation of free labor operated, just like for rent, without having any real function in the process of production' (2010, p. 102). He draws on passages from Capital Volume 3, where Marx himself 'questions the terms of the opposition between profit and rent as well as the limits of a definition of rent reduced to ground rent only' (Vercellone, 2010, p. 99). Marx notes that as the entrepreneur disappears and is replaced by the manager in production who 'takes care of all real functions that fall to the functioning capitalist as such', the capitalist 'vanishes from the production process as someone superfluous' (Marx, 1981, p. 512). Here, in contrast to Caraway's (2011) insistence, the distinction between profit and rent is already blurred. Since both derive from the exploitation of surplus labour, the capitalist who extracts a share of surplus value as a profit redistributed to shareholders is little different from the landlord who extracts a share as rent, or the banker who extracts a share as interest on loans. In any case, the provider of finance or land extracts a share of surplus value, but in no way contributes to the coordination of production and thereby to the production and realisation of surplus value, as the classical entrepreneur of political economy was assumed to do. Vercellone suggests that this tendency has been exacerbated by the socialisation of labour and the rise of the general intellect as now even the formerly managerial work of organizing and coordinating labour has been taken on by the workforce itself (2010, pp. 99-102).

Social media platforms like Facebook, in this reading, are only one example of how capital appropriates value from socialized, free labour. While many social networks come and go - take for instance Bebo, Orkut or Friendster (Lovink, 2011, p. 6) - Facebook's success lies in its ability to draw in and keep users, thereby generating network economics that lock users in. For example, users can easily find and connect with friends by allowing it to search their email address books, or through integration with other social media, like Twitter or Instagram (which Facebook recently acquired). Once dominant, being on Facebook, although obviously not compulsory, becomes increasingly important for many people in both work and life. Gregg notes, for example, how Facebook operates through a kind of 'compulsory friendship' (2011, p. 96) when used by 
creative workers to promote themselves and their products and maintain presence, or when colleagues are expected to 'friend' one another in the constitution of a work-based community.

These techniques combine with strategies such as 'data lock' (Scholz, 2010, p. 246) to enable Facebook to capture the free labour of users. Facebook is able to extract a 'tithe' of free labour from its users because it has achieved an overwhelming network advantage over its competitors. As Scholz (2010, p. 246) notes, not 'only is Facebook difficult to leave for personal, social, and professional reasons', but when exiting it is nearly impossible to 'fully extract the images, links, wall-posts, and all the "public" interactions that are linked to one's identity'. If any one user is unhappy with Facebook, and defects to use an alternative platform, they effectively lose access to those friends who are already on Facebook. This data lock ensures that users find it hard to leave and that Facebook can build a stable database that it can use to analyse user profiles for targeted advertising or predict consumer behaviour through the sentiment analysis discussed by Andrejevic (2012) and other forms of big data analytics.

A second strategy is known as 'walled gardening', where users cede control of their data but other Internet sites are excluded from direct connectivity or access to that data. This is most clearly demonstrated by the 'Like' button, which has partially subsumed the function of the hyperlink in the World Wide Web (Halpin, 2012). The functioning of the web is dependent on the links that produce it as a hypertext, which, not incidentally, serves as the 'crowdsourcing' basis of Google's search algorithm (Dyer-Witheford, 2009, p. 74). Although the 'Like' button is based on open source software designed to keep the web open (Halpin, 2012), in Facebook's adaptation it draws all traces of social relations into a closed, proprietary site, or 'walled garden'. This means that the data traces left by user activities such as 'liking', 'friending' and 'recommending' are closed to Google and other search engines, giving Facebook an effective monopoly over the data these activities generate (Gerlitz and Helmond, 2013). Furthermore, the 'Like' button increasingly structures peoples' usage of the Internet more generally, placing Facebook at the centre of their browsing.

These two strategies demonstrate how Facebook captures the free labour of its users whilst simultaneously suggesting that Vercellone and Virno overemphasise the autonomy of free labour as an aspect of the general intellect. Capital seems to work precisely by limiting the free flow of information, via intellectual property regimes or privatised platforms such as Facebook, thereby 'discouraging the diffusion of the general intellect', as Smith (2013, p. 252) puts it. At the same time, even though it is now clearer how users are attracted to the site, it is not obvious yet how they are made to gift their free labour. The argument concerning 'the becoming rent of profit' suggests that capital stays at a distance from that labour, withdrawing from direct control over production (Vercellone, 2010). As the discussion in this section shows, this is is not the case with social media sites like Facebook, where free labour is controlled through the structuring of access 
to, and the forms of, communication via the design and enclosure of the platform (cf. Smith, 2013, p. 252-253).

This is not to suggest a simple technologically determined outcome to value production and appropriation, however. As we argue with Harvie (2005) and Terranova (2004), we can expect to witness a struggle over the form and productivity of free labour. Vercellone notes how 'the old dilemma about the control of labor reappears in a new form', with capital not only dependent on labour's knowledge but also its active cooperation (2010, p. 106). He suggests that capital responds via a prescription of subjectivity, competitive pressure and precarious labour (ibid.) i.e. strategies that work mostly through the labour market. However, if consent is produced at the point of production (Burawoy, 1979), a clearer understanding of how free labour is controlled and thus made productive in the labour process is required. For this, we need to return to Marxist organization studies.

\section{Managing and controlling labour by code and protocol}

We are now at a point where we can more clearly articulate how Marxist organization studies can respond to the challenge posed by Facebook. Where the 'audience commodity' approach made the case for understanding user activity on Facebook as labour, and where the argument regarding 'the becoming rent of profit' partly explained how user labour is captured on Facebook, Marxist organization studies can build on these insights and contribute to the debate by explaining and exploring how precisely this captured free labour is made productive.

With a focus on the struggle over the productivity of free labour, as we outlined above with Harvie (2005) and Terranova (2004), Marxist organization studies shows that much of the labour employed directly by Facebook is actually concerned with the management of the free labour of its users. When Facebook employees code algorithms for data extraction, or develop protocols like the 'Like' button, they are effectively managing. They are guiding user behaviour in such a way that it is more likely to create marketable data, or generate content that will draw other users' attention, which can subsequently be commodified via advertising. In this light, the more than 4500 direct employees of Facebook are better understood as managers of the more than one billion free labour force/user audience. In producing the Facebook platform, they simultaneously produce a non-commodified product without a price - the platform - and, through that platform, manage the free labour of users in order to render it productive of commodities that can be exchanged for money and profit: user data, content and audience attention.

Marxist organization studies also understands that managerial labour has two sides, namely a productive side involved in the organization of production, and an unproductive side concerned 
merely with reproducing capitalist relations of production (see Willmott, 1997; Armstrong, 1989). The first face of managerial labour on Facebook involves producing the social media commodity. This involves work such as coding algorithms for data extraction, and working on databases to provide useful statistics to differentiate Facebook's products by audience. The second face can be analytically distinguished, even though practically it is part of the same process. By developing protocols for user engagement, which encourages users to produce content and data, as e.g. with the 'Like' button, Facebook employees are managing the free labour of its users in such a way as to increase the value to be extracted from it. This double face reflects the work of any manager in a capitalist enterprise, whose role is 'simultaneously productive and exploitative' (Adler, 2009, p. 66). Understanding the work of Facebook employees in this dual sense thereby helps us to understand how free labour is managed and commodified.

A second contribution of Marxist organization studies concerns the concrete exploration of how free labour is managed in the social media labour process. The question of control is by no means absent from the literature on the audience commodity or the general intellect. Caraway employs a classic definition of direct control and insists that the product of audience labour is 'not under sufficient control by the capitalist to warrant the reduction of audience subjectivity to the status of an owned commodity' (2011, p. 701). Fuchs deploys a more novel concept of control, arguing that users are under 'the ideological control of capitalists that possess control over the means of communication' (2014b, p. 91), a control that is enhanced by the social exclusion that results from not using social media like Facebook. Andrejevic, while less rigid in his conception of control than Caraway, adopts a conception of control that assumes subordination of subjective preference and desire, rather than the production or structuring of such. For example, he argues that the 'fact of exploitation need not prevent workers from taking pleasure in their craft or in the success of a collaborative effort well done' (Andrejevic, 2012, p. 153).

This literature appears to be largely unaware of Marxist organization studies, yet it could benefit immensely from such an encounter. Caraway's rigidly top-down concept of direct control, for example, has been superseded by LPT in its analysis of new forms of control, such as neonormative control (Sturdy et al., 2010). Andrejevic's comments on the possibility of pleasure despite exploitation bypasses debates in organization studies over the possibility of pleasure, authenticity and community precisely as mechanisms of control (e.g. Fleming, 2009; Land and Taylor, 2011). The forms of self-expression realized in free labour for Facebook might not, from this perspective, be so different from those found in the 'no-collar' workers in New York's Silicon Alley (Ross, 2004). Marxist organization studies can here offer a more concise account of how free labour is controlled and thus made productive. 
Yet, this is also where Marxist organization studies, due to not having paid sufficient attention to free and digital labour, encounters its own weak spots. Free, digital labour is necessarily controlled in different ways from other forms of labour. It is not even controlled in the same way as other forms of digital labour, such as the coding work 'crowdsourced' by Amazon's Mechanical Turk, where willing labourers bid for contracts that are paid a piece (see Aytes, 2013). Nor is it comparable to the 'playbour' taking place in the sweatshops of the Global South where workers play games to farm virtual gold - such as weapons or avatars - later sold to customers in the Global North (Goggin, 2011). Neither is the form of control similar to that found in call centres (Bain and Taylor, 2000), since it is neither conducted within a top-down power relationship or primarily regulated by discipline and surveillance. With social media's ability to constantly trace user behaviour in any case, surveillance is a given. The challenge is how to valorize these traces (Cohen, 2008) and ensure that behaviour leaves a trace that can be valorized. The massive datasets produced by Facebook users are analyzed in order to better predict the behaviours of users. Through this prediction users are controlled by providing what they want, when they want it, even if they are not yet aware of these desires (Andrejevic, 2011).

It is, therefore, not so much a question of discouraging misbehaviour as to encourage user activity that produces the right kind of content and data to be valorized, by prescribing certain kinds of user activity via the user interface and the codes and protocols that ensure its function. To give one example, the 'Like' button is not only a technology of enclosure (Halpern, 2012), it also facilitates specific forms of interaction and prevents others. In fact, it is probably the most reductive kind of code there is, allowing only two options: either a user 'likes' something (a link, a post, an article, a video, whatever), or they don't interact. There is not even an option to 'dislike'. The same can be said about many of the other design features of the Facebook platform: it prescribes and enables certain digital actions and prohibits others. In effect, it provides a restricted grammar, or set of protocols, for social networking that structure communication in such a way as to maximize the production of both user data and users' friends-as-audience (see Gerlitz and Helmond, 2013).

A focus on this 'protocological control', as we might call it following Galloway (2004), in the labour process would also open a space for a third contribution from Marxist organization studies: an insistence on contestation and resistance. Caraway (2011, p. 700) rightly criticizes Smythe $(1977 ; 1981)$ for denying the subjectivity and agency of media users, thereby disregarding the way capitalist labour processes are marked by a fundamental antagonism. While capitalist control is never complete and depends upon a degree of consent (Burawoy, 1979), it also brings with it forms of resistance specific to the social relations of production. Scholz (2010, p. 251) suggests three in the case of Facebook: users could provide 'fake data' in order to skew data and make it unusable; users could hack Facebook, e.g. by creating project sites that raise political awareness through viral networking; or users could rise up, with the risk of this 
discontent being fed back into a consumer feedback loop. Users also already interrupt the valorization process of Facebook, e.g. by using ad blockers in browsers, which effectively avoids users becoming audiences of advertising, or by the browser plug-in 'Facebook Demetricator', which makes all metrics on Facebook disappear and thereby intervenes in its protocols.

\section{Conclusions}

We argued above that an exclusive focus on wage labour does not allow us to account for the way in which value is produced in Facebook, social media in general, or many other valorization processes (Böhm and Land, 2012). We concurred with Harvie's (2005) argument that such a classical Marxist focus neglects capital's continuous (re)organization of all forms of labouring activity, including what we identified as 'free labour' (Terranova, 2004). While the 'audience commodity' approach (Smythe, 1977; Fuchs, 2014b) provides a strong case for considering user activity as labour, it cannot adequately explain how this labour is captured and rendered productive. Whilst the argument for a 'becoming rent of profit' (Marazzi, 2010; Vercellone, 2010) helps us to understand some of the ways in which free labour is captured, it does not provide an adequate framework for analysing the processes of control in the labour process. As such, we have argued for a return to Marxist organization studies as a means of apprehending the dialectical forms of control and resistance on Facebook.

In making this argument we have sought to contest the current constitution of Marxist organization studies with its focus on wage labour and 'the everyday contradictions of the capitalist firm' (Adler, 2007, p. 1339), whilst appreciating its continued importance for understanding management, labour, and organization in digital capitalism, albeit with some modifications. A Marxist organization studies, in our view, must not shy away from rethinking some key Marxist concepts and their relations, and this also involves understanding contemporary business models, not only those of the web 2.0, as involving some very advanced means of capturing free labour and what we called, with Galloway (2004), 'protocological control'. Marxist organization studies can, on that basis, explain how free labour is managed and made productive and, in the fashion of LPT, provide analyses of the resistances to this work regime, e.g. user-uprisings, fake data or exit as described by Scholz (2010, p. 251).

We provide Facebook here as an indicative example of how free labour in general, and digital labour specifically, has gained prominence in contemporary capitalism (Caffentzis, 1999; Terranova, 2004; Ross, 2012). Facebook, and social media more generally, challenge Marxist organization studies to explore in more detail the reconfigurations of labour that they bring about and how the free labour of Facebook use is articulated with more conventional examples of wage labour. Gregg provides one example of such an analysis when she finds that Facebook functions 
both as a kind of "'security blanket" for workers', making 'bearable all of the potentially overwhelming encounters of life online and on the job' (2011: 88), and as a space for 'a new form of prospective labor' (Gregg, 2011: 89) used to promote oneself and to maintain 'contacts' who might prove useful in gaining employment in the future. A full account of how labour is reconfigured would also need to consider the production and servicing of the material technologies and infrastructures that enable the labour of communication, mapping a global production network (Levy, 2008) that encompasses everything from Coltan mining in the Congo and the cooling of massive data storage warehouses, to the sales workers in electronics stores (Fuchs, 2014b).

Whilst we clearly need to be cautious of overemphasising capital's command, Coté and Pybus (2007) suggest that it is precisely on social networking sites such as Facebook (although their example is MySpace) that we 'learn to immaterial labour 2.0', i.e. it is here that our 'digital bodies' are shaped and where the capital relationship is reproduced. Contextualizing this analysis in a cycle of net struggles, Dyer-Witheford suggests that the Web 2.0 appears as 'information capital's compromise with immaterial labor, providing it with limited, semiautonomous options for content creation in return for overall subordination' (2009, p. 76; see also Lovink, 2011). With Facebook currently the most fashionable example of a networked media landscape dominated by corporations and privatized communication infrastructure, it is worth asking how this dominance of capital manages to sustain itself, and what kinds of alternative organizations, or political demands, may be required to challenge that domination.

\section{References}

Adler, P. (2007). The future of critical management studies: A paleo-Marxist view. Organization Studies, 28, 1313-1345.

Adler, P (2009). Marx and organization studies today. In P. Adler (ed.) The Oxford handbook of sociology and organization studies: classical foundations (62-91). Oxford: Oxford University Press.

Adorno, T. \& Horkheimer, M. (1997). Dialectic of enlightenment. London: Verso.

Andrejevic, M. (2009). Exploiting YouTube: contradictions of user-generated labor. In P. Vonderau \& P. Snickars (eds) The YouTube reader (33-51). Stockholm: National Library of Sweden.

Andrejevic, M. (2011). The work that affective economies does. Cultural Studies, 24, 604-620.

Andrejevic, M. (2012). Estranged free labor. In T. Scholz (ed.) Digital labor: the Internet as playground and factory (149-164). London: Routledge. 
Armstrong, P. (1989). Management, labour process and agency. Work, Employment \& Society, 3, 307-322.

Arvidsson, A. (2005). Brands: a critical perspective. Journal of Consumer Culture, 5, 235-258.

Arvidsson, A. \& Colleoni, E. (2012). Value in informational capitalism and on the Internet. The Information Society, 28, 135-150.

Aytes, A. (2013). Return of the crowds: Mechanical Turk and neoliberal states of exception. In T. Scholz (Ed.) Digital labor: the Internet as playground and factory (79-97). London: Routledge.

Bain, P. \& Taylor, P. (2000). Entrapped by the 'electronic panopticon'? Worker resistance in the call centre. New Technology, Work and Employment, 15, 2-18.

Beverungen, A. (2009). Whither Marx in the business school? Phd Thesis, University of Leicester. https://lra.le.ac.uk/handle/2381/8202, accessed 1 October 2012.

Böhm, S. \& Land, C. (2012). The new 'hidden abode': reflections on value and labour in the new economy. The Sociological Review, 60, 217-240.

Braverman, H. (1974). Labor and monopoly capital: the degradation of work in the twentieth century. London: Monthly Review Press.

Burawoy, M. (1979). Manufacturing consent: changes in the labour process under monopoly capitalism. Chicago: University of Chicago Press.

Burston, J., Dyer-Witheford, N. \& Hearn, A. (2010). Digital labour: workers, authors, citizens. ephemera: theory \& politics in organization, 10, 214-221.

Caffentzis, G. (1999). The end of work or the renaissance of slavery? A critique of Rifkin and Negri. Commons Sense, 24, 20-38.

Caraway, B. (2011). Audience labor in the new media environment: a Marxist revisiting of the audience commodity. Media, Culture \& Society, 33, 693-708.

Cleaver, H. (2001). Work is still the central issue! New words for new worlds. In A.C. Dinerstein \& M. Nearly (eds) The labour debate: an investigation into the theory and reality of capitalist work (135-149). Aldershot: Ashgate.

Cohen, N.S. (2008). The valorization of surveillance: towards a political economy of Facebook. Democratic Communique, 22, 5-22.

Coté, M. \& Pybus, J. (2007). Learning to immaterial labour 2.0: MySpace and social networks. ephemera: theory \& politics in organization, 7, 88-106.

Dalla Costa, M. \& James, S. (1975). The Power of women and the subversion of the community. Berlin: Falling Wall Press.

Dyer-Witheford, N. (2009). Cycles of struggle, lines of net flight. In G.J. Leckie \& J.E. Buschman (eds) Information technology in librarianship (61-81). London: Libraries Unlimited.

Facebook (2013). Annual Report 2012. Menlo Park: Facebook Inc. http://investor.fb.com/annuals.cfm, accessed 2 September 2013. 
Fleming, P. (2009). Authenticity and the cultural politics of work. Oxford: Oxford University Press.

Fleming, P. \& Mandarini, M. (2009). Towards a workers' society? New perspectives on work and emancipation. In M. Alvesson, T. Bridgman, \& H. Willmott (eds) The Oxford handbook of critical management studies (328-344). Oxford: Oxford University Press.

Fuchs, C. (2012a). The political economy of privacy on Facebook. Television \& New Media, 13, 139-159.

Fuchs, C. (2014a). Social media: a critical introduction. London: Sage.

Fuchs, C. (2014b). Digital Labour and Karl Marx. Abingdon: Routledge.

Galloway, A. (2004) Protocol: how control exists after decentralization. Cambridge MA: MIT Press.

Gerlitz, C. \& Helmond, A. (2013). The like economy: social buttons and the data-intensive web. New Media \& Society, online first.

Goggin, J. (2011). Playbour, farming and leisure. ephemera: theory \& politics in organization, $11,357-368$.

Grassman, R. \& Case, P. (2009). Virtual intimacy: desire and ideology in virtual social networks. In N. Panteli (ed.) Virtual social networks (175-193). London: Palgrave Macmillan.

Gregg, M. (2011) Work's intimacy. Cambridge: Polity.

Halpin, H. (2012). The hidden history of the "Like" button. Presentation at Unlike Us \#2 Conference, Amsterdam, 10 March.

http://networkcultures.org/wpmu/unlikeus/2012/03/10/harry-halpin-on-the-hidden-historyof-the-like-button/, accessed 8 December 2012.

Hardt, M. \& Negri, A. (1994). Labor of dionysus. Minneapolis: Universit of Minnesota Press.

Harney, S. (2007). Socialisation and the business school. Management Learning, 38, 139-153.

Hartmann, H. (1979). The unhappy marriage of Marxism and Feminism: Towards a more progressive union. Capital \& Class, 3, 1-33.

Harvie, D. (2005). All labour produces value for capital and we all struggle against value. The Commoner, 10, 132-171.

Heckscher, C. and Adler, P. (eds.) (2006). The firm as collaborative community: the reconstruction of trust in the knowledge economy. Oxford: Oxford University Press.

Henninger, M. (2007). Doing the maths: reflections on the alleged obsolescence of the law of value under post-Fordism. ephemera: theory \& politics in organization, 7, 158-117.

Henwood, D. (2003). After the new economy: the binge... and the hangover that won't go away. New York: The New Press.

Jaros, S. (2005). Marxian critiques of Thompson's (1990) 'core' labour process theory: an evaluation and extension. ephemera: theory \& politics in organization, 5, 5-25.

Jhally, S. \& Livant, B. (1986). Watching as working: the valorization of audience consciousness. Journal of Communication, 36, 124-143.

Lanchester, J. (2012) Marx at 193. London Review of Books, 34/7, 7-10. 
Land, C. \& Taylor, S. (2011). Be who you want to be: branding, identity, and the desire for authenticity. In M. Brannan et al. (eds) Branded lives: the production and consumption of meaning at work. Cheltenham: Edward Elgar.

Land, C. \& Taylor, S. (2010). Surf's up: Life, balance and brand in a new age capitalist organization, Sociology, 44, 395-413.

Levy, D. (2008). Political contestation in global production networks. Academy of Management Review, 33, 943-963.

Lovink, G. (2011). Networks without a cause: a critique of social media. Cambridge: Polity.

Lucio, M. M. \& Stewart, P. (1997). The paradox of contemporary labour process theory: the rediscovery of labour and the disappearance of collectivism. Capital \& Class, 19/62, 49-77.

Mandarini, M. (2005). Antagonism, contradiction, time: conflict and organization in Antonio Negri. The Sociological Review, 53, 192-214.

Marazzi, C. (2010). The violence of financial capitalism. In A. Fumagalli \& S. Mezzadra (eds) Crisis in the global economy: financial markets, social struggles, and new political scenarios (17-60). New York: Semiotext(e).

Marx, K. (1973). Grundrisse: foundations of the critique of political economy, trans. M. Nicolaus. London: Penguin.

Marx, K. (1976). Capital: A critique of political economy, vol. 1, trans. B. Fowkes. London: Penguin.

Marx, K. (1981). Capital: A critique of political economy, vol. 3, trans. D. Fernbach. London: Penguin.

Meiksins, P. (1981). Productive and unproductive labor and Marx's theory of class. Review of Radical Political Economics, 13, 13-42.

Miller, D. (2011). Tales from Facebook. Cambridge: Polity Press.

Mohun, S. (1996). Productive and unproductive labour in the labor theory of value. Review of Radical Political Economics, 28, 30-54.

Muhr, S.L. \& Pedersen, M. (2011). Faking it on Facebook. In D.E. Wittkower (ed.) (2011) Facebook and philosophy: what's on your mind? (265-275) Chicago: Open Court.

Ross, A. (2004). No collar: the humane workplace and its hidden costs. New York: Temple University Press.

Ross, A. (2012). In search of the lost paycheck. In T. Scholz (ed.) Digital labor: The Internet as playground and factory (13-32). London: Routledge.

Rowlinson, M. \& Hassard, J. (1994). Economics, politics and labour process theory. Capital \& Class, 18, 65-97.

Scholz, T. (2008). Market ideology and the myths of Web 2.0. First Monday, 3. http://firstmonday.org/article/view/2138/1945, accessed 26 October 2012.

Scholz, T. (2010). Facebook as playground and factory. In D.E. Wittkower (ed.) Facebook and philosophy: what's on your mind? (241-252). Chicago: Open Court. 
Scholz, T. (ed.) (2012). Digital labor: The Internet as playground and factory. London: Routledge.

Smith, T. (2013). The 'general intellect' in the Grundrisee and beyond. Historical Materialism, 21, 235-255.

Smythe, D. W. (1977). Communications: blindspot of Western Marxism. Canadian Journal of Political and Social Theory, 1, 1-27.

Smythe, D. W. (1981). On the audience commodity and its work. In M. G. Durham, and D. M. Kellner (eds) Media and cultural studies (230-56). Malden, MA: Blackwell.

Spencer, D. (2000). Braverman and the contribution of labour process analysis to the critique of capitalist production - twenty-five years on. Work, Employment \& Society, 14(2), 223-243.

Sturdy, A., Fleming, P. \& Delbridge, R. (2010). Normative control and beyond in contemporary capitalism. In P. Thompson \& C. Smith (eds) Working life: renewing labour process analysis (113-135). Basingstoke: Palgrave Macmillan.

Terranova, T. (2004). Network culture: politics for the information age. London: Pluto Press.

Thompson, P. (1990). Crawling from the Wreckage: The Labour Process and the Politics of Production. In D. Knights, \& H. Willmott (eds). Labour process theory (95-124). Basingstoke: Macmillan.

Thompson, P. \& Smith, C. (2009). Labour power and labour process: contesting the marginality of the sociology of work. Sociology, 43, 913-930.

Vercellone, C. (2007). From formal subsumption to general intellect. Historical Materialism, 15, 13-36.

Vercellone, C. (2010). The crisis of the law of value and the becoming-rent of profit. In A. Fumagalli \& S. Mezzadra (eds) Crisis in the global economy: financial markets, social struggles, and new political scenarios (85-118). New York: Semiotext(e).

Vidal, M. (2013). Low-autonomy work and bad jobs in postfordist capitalism. Human Relations, $66 / 4,587-612$.

Virno, P. (2007). General intellect. Historical Materialism, 15, 3-8.

Willmott, H. (1997). Rethinking management and managerial work: capitalism, control, and subjectivity. Human Relations, 50, 1329-1359.

Wilson, R.E., Gosling, S.D. \& Graham, L.T. (2012). A review of Facebook research in the social sciences. Perspectives on Psychological Science, 7, 203-220. 